\title{
PERTUMBUHAN KENTANG HITAM (Coleus tuberosum) VARIETAS LOKAL DARI STEK PADA BERBAGAI MEDIA TANAM
}

\section{GROWTH OF BLACK POTATO (Coleus tuberosum) LOCAL VARIETIES FROM CUTTINGS IN A VARIETY OF PLANTING MEDIA}

\author{
Rahmad Jumadi ${ }^{1}$ dan Suhaili ${ }^{2}$ \\ ${ }^{1,2}$ Dosen Program Studi Agroteknologi, Fakulats Pertanian \\ Universitas Muhammadiyah Gresik \\ Jalan Sumatra 101 GKB Gresik 61121 \\ *E-mail: $\underline{\text { rahmad@umg.ac.id }}$
}

\begin{abstract}
ABSTRAK
Dalam rangka mewujudkan kemandirian pangan perlu diupayakan pengembangan tanaman alternatif penghasil pangan selain padi, tanaman umbi-umbian layak dijadikan alternatif untuk dikembangkan yaitu tanaman kentang. Selain itu produksi kentang masih rendah, salah satu penyebab adalah belum banyaknya petani yang menggunakan benih kentang bermutu karena ketersediaanya yang masih langka dikalangan petani. Pertumbuhan optimal bagi tanaman kentang adalah menghendaki kondisi tanah dengan fisik yang poros atau remah, permeabilitas nya bagus, gembur, banyak memiliki bahan organik dan sedikit mengandung pasir karena produksi tanaman kentang yang diharapkan berupa umbi yang berkembang dibawah permukaan tanah. Hasil penelitian Hidayat (2016) menunjukkan bahwa perlakuan dengan komposisi media tanam yang berbeda memberi pengaruh terhadap jumlah daun dan lebar tajuk, panjang tunas, dan umbi kentang yang dihasilkan. Penelitian ini mempunyai tujuan dari untuk mengetahui potensi hasil tanaman kentang hitam varietas lokal Gresik yang ditanam pada berbagai komposisi media tanam. Rancangan penelitian ini memakai Rancangan Acak Lengkap (RAL) menggunakan aplikasi perlakuan jenis media tanam, yaitu : $\mathrm{M}_{1}$ komposisi : (arang sekam : cocopeat : tanah); M2 komposisi (arang sekam: guano: tanah) dan M3 komposisi (arang sekam : pupuk kandang : tanah). Data yang dihasilkan dari penelitian ini kemudian dianalisis secara statistik dengan uji F pada taraf 5\%, selanjutnya akan dijuji dengan uji lanjutan BNT pada tingkat kepercayaan 5\%. Hasil penelitian menunjukkan bahwa aplikasi penggunaan media tanam dengan komposisi cocopeat dan pupuk kandang mampu meningkatkan pertumbuhan kentang hitam varietas lokal asal stek, dan aplikasi penggunaan media tanam dengan komposisi pupuk guano belum mampu meningkatkan pertumbuhan kentang hitam varietas lokal asal stek hal ini diduga proses dekomposisi belum optimal
\end{abstract}

Kata kunci: stek, media tanam, kentang hitam

\section{PENDAHULUAN}

Kebutuhan terhadap beras sebagai bahan pangan utama atau pokok masyarakat Indonesia terus meningkat setiap tahunnya bersamaan dengan laju pertambahan jumlah penduduk. Diperkirakan jumlah penduduk Indonesia tahun 2025 mencapai lebih kurang 300 juta 
jiwa yang tentunya semuanya akan membutuhkan bahan pangan utama yaitu beras dalam jumlah yang sangat banyak.

Menurut Suswono (2011), pada tahun 2014 saja pemerintah Indonesia telah menentukan target jumlah produksi beras sebanyak 75,7 juta ton gabah kering giling. Peningkatan jumlah produksi beras sacara nasional sangat tergantung pada padi sawah, sedangkan ketersidaan luas lahan sawah secara nasional cenderung terus menyusut akibat alih fungsi lahan produktif untuk pemakaian untuk usaha non-pertanian. Keadaan tersebut tentu akan sangat memberatkan Pemerintah Indonesia untuk dapat mencukupi kebutuhan tanpa harus mendatangkan dari luar negeri jika hanya mengandalkan pada produksi padi lahan sawah (Human, 2015).

Pertambahan kebutuhan terhadap beras dikhawatirkan akan mendorong pemerintah mengambil kebijakan terus melakukan impor. Hal ini tidak boleh terjadi karena dapat menggoyahkan ketahanan pangan Nasional. Kebijakan melakukan import selain menjadikan bangsa Indonesia selalu tergantung kepada negara lain juga menyebabkan devisa kita menurun. Oleh karena itu diperlukan upaya lain untuk meningkatkan produktifitas tanaman padi atau melakukan diversifikasi budidaya tanaman lain selain padi yang mempunyai potensi cukup besar menghasilkan sumber karbohidrat alternatif.

Banyak jenis tanaman sebagai penghasil pangan, tanaman umbi-umbian layak dijadikan alternatif untuk dikembangkan. Tanaman umbi-umbian merupakan salah satu jenis tanaman yang berpotensi sebagai sumber pangan alternatif yang memiliki masa depan yang sangat baik untuk dikembang-luaskan secara komersial di Indonesia, karena didukung oleh kondisi iklim agroekologis dan lahan yang tersedia cukup luas terutama di lahan marjinal. Hampir di seluruh daerah di Indonesia dapat di tanam dan tumbuh serta menghasilkan berbagai macam umbi-umbian, antara lain singkong, ubi jalar, kentang, gembili, uwi, gadung. Sebagai tanaman penghasil karbohidrat untuk bahan pangan alternatif, tanaman umbi-umbian sangat besar peluangnya untuk bersaing dengan beras dan jagung, karena beranekaragamnya tanaman tersebut.

Dari berbagai macam tanaman umbiumbian tanaman kentang dapat dipilih untuk dikembangkan sebagai tanaman penghasil pangan alternatif. Namun demikian menurut Duaja (2012) terbatasnya lahan yang cocok untuk pengembangan kentang yaitu daerah di dataran tinggi saja sehingga menyebabkan lahan untuk pertanaman kentang menjadi terbatas. Oleh karena itu perlu dicaridan dikembangkan tanaman kentang yang secara alami mampu tumbuh dan berkembang di daerah dataran rendah.

Kentang hitam merupakan jenis tanaman kentang yang dapat berkembangdareah dengan baik di dataran rendah yang mempunyai potensi sangat baik sebagai sumber pangan alternatif, namun pembudidayaannya di masyarakat termasuk di Gresik saat ini semakin berkurang. Kondisi tersebut tidak boleh dibiarkan dan seharusnya diupayakan untuk mengajak masyarakat untuk menanam kembali kentang hitam karena selain sebagai tanaman penghasil bahan pangan, tanaman kentang hitam juga berpotensi menjadi tanaman penghasil obat-obatan. Pemerintah Daerah mempunyai peran penting dalam upaya meningkatkan kembali semangat dan ghairah masyarakat untuk menanam tanaman kentang hitam yang sudah mulai 
menurun luas areal penanamannya.

Pertumbuhan optimal bagi tanaman kentang adalah menghendaki kondisi tanah dengan fisik yang poros atau remah, permeabilitas nya bagus, gembur, banyak memiliki bahan organik dan sedikit mengandung pasir karena produksi tanaman kentang yang diharapkan berupa umbi yang berkembang dibawah permukaan tanah. Hasil penelitian Hidayat (2016) menunjukkan bahwa perlakuan dengan komposisi media tanam yang berbeda memberi pengaruh terhadap jumlah daun dan lebar tajuk, panjang tunas, dan umbi kentang yang dihasilkan.

Mengingat potensi yang dimiliki tanaman kentang hitam, maka upaya pengembangan tanaman tersebut perlusegera dilakukan, baik oleh perorangan maupun oleh Pemerintah. Untuk membantu peran Pemeritah dalam mengembangkan tanaman kentang hitam maka perlu dilakukan penelitian tentang tanaman kentang hitam dengan judul "Optimasi Budidaya Kentang Hitam (Coleus Tuberosum) Varietas Lokal Dari Umbi Mikro dan Stek Pada Berbagai Media Tanam"

\section{METODE}

Penelitian ini dilaksanakan selama Januari - Juni 2020 di Laboratorium Percobaan Fakultas Pertanian Universitas Muhammadiyah Gresik, Desa Randuagung Kec. Kebomas Kab. Gresik, Jawa Timur dengan ketinggian tempat \pm 10 m dpl. Sebagai sumber bahan pada penelitian ini adalah benih kentang Hitam varietas lokal berupa stek mini siap tanam berdaun 2-3, Media tanam (tanah topsoil, pupuk kandang, arang sekam, cocopeat dan guano), fungisida, insektisida.

Rancangan penelitian ini memakai
Rancangan Acak Lengkap (RAL) menggunakan aplikasi perlakuan jenis media tanam, Perlakuan terdiri dari 3 perlakuan yaitu : $\mathbf{M}_{1}$ komposisi : (arang sekam : cocopeat : tanah); $\mathbf{M}_{2}$ komposisi (arang sekam: guano: tanah) dan $\mathrm{M}_{3}$ komposisi (arang sekam : pupuk kandang : tanah). Seiap perlakuan diulang 3 kali sehingga diperoleh sembilan satuan percobaan. Data yang dihasilkan dari penelitian ini kemudian dianalisis secara statistik dengan uji $\mathrm{F}$ pada taraf $5 \%$, selanjutnya akan dijuji dengan uji lanjutan BNT pada tingkat kepercayaan 5\%. jika $\mathrm{F}$ hitung lebih besar dari F Tabel 5\%

\section{HASIL DAN PEMBAHASAN}

\section{Pengamatan Pertumbuhan Tanaman}

Dari analisis sidik ragam diketahui bahwa berbagai perlakuan ( $\left.\mathrm{M}_{1}, \mathrm{M}_{2}, \mathrm{M}_{3}\right)$ berpengaruh nyata terhadap pertumbuhan tanaman yaitu tinggi tanaman, Jumlah cabang dan luas daun. Pengaruh aplikasi media tanam terhadap tinggi tanaman Kentang hitam disajikan pada Tabel 1 .

Tabel 1. Rata-rata Tinggi Tanaman Kentang hitam pada Berbagai Media Tanam

\begin{tabular}{cc}
\hline Perlakuan & Tinggi tanaman $(\mathbf{c m})$ \\
\hline $\mathrm{M}_{1}$ & $26,17 \mathrm{~b}$ \\
$\mathrm{M}_{2}$ & $14,04 \mathrm{a}$ \\
$\mathrm{M}_{3}$ & $25,91 \mathrm{a}$ \\
\hline
\end{tabular}

Keterangan : Angka-angka pada lajur tinggi tanaman yang diikuti huruf kecil yang sama berbeda tidak nyata menurut uji BNT taraf $5 \%$

Pengaruh aplikasi media tanam terhadap jumlah cabang tanaman Kentang hitam disajikan pada Tabel 2. 


\section{Tabel 2. Rata-rata Jumlah cabang Kentang hitam Berbagai Media Tanam}

\begin{tabular}{cc}
\hline Perlakuan & Jumlah cabang \\
\hline $\mathrm{M}_{1}$ & $9,33 \mathrm{~b}$ \\
$\mathrm{M}_{2}$ & $5,60 \mathrm{a}$ \\
$\mathrm{M}_{3}$ & $9,47 \mathrm{~b}$ \\
\hline
\end{tabular}

Keterangan : Angka-angka pada lajur tinggi tanaman yang diikuti huruf kecil yang sama berbeda tidak nyata menurut uji BNT taraf $5 \%$

Pengaruh aplikasi media tanam terhadap luas daun tanaman Kentang hitam disajikan pada Tabel 3 .

Tabel 3. Rata-rata Luas Daung Kentang hitam pada Berbagai Media Tanam

\begin{tabular}{cc}
\hline Perlakuan & Luas Daun $\left(\mathbf{c m}^{2}\right)$ \\
\hline $\mathrm{M}_{1}$ & $31,89 \mathrm{~b}$ \\
$\mathrm{M}_{2}$ & $12,91 \mathrm{a}$ \\
$\mathrm{M}_{3}$ & $33,06 \mathrm{~b}$ \\
\hline
\end{tabular}

Keterangan : Angka-angka pada lajur tinggi tanaman yang diikuti huruf kecil yang sama berbeda tidak nyata menurut uji BNT taraf $5 \%$

Pada Tabel 1, 2 dan 3 dapat dilihat bahwa pada tinggi tanaman, jumlah cabang dan luas daun pada media tanam cocopeat dan pupuk kandang (M1 dan M3) lebih baik jika dibandingkan media tanam yang ada kandungan guanonya (M2). Hal ini disebabkan oleh kandungan cocopeat dalam media tanam mampu menyimpan air yang baik sehingga ketersediaan air selau cukup dan dapat dengan mudah melarutkan komponen nutrisi yang lain sehingga mudah diserap oleh tanaman.

Pupuk kandang selain memiliki kandungan unsur hara yang lengkap juga memperbaiki sifat fisik tanah menjadi gembur. Penambahan bahan organik yang berasal dari pupuk kandang ke tanah secara otomatis akan semakin menambah populasi mikroba-mikroba dekomposer yang telah ada sebelumnya dan pengaruhnya adalah proses penguraian bahan organik menjadi hara yang dibutuhkan tanaman semakin cepat. Tanah yang lembab akibat penggunakan bahan organik juga membuat keadaan yang ideal bagi perkembangan aneka mikrobia yang ada di dalam tanah. Pupuk kandang dan cocopeat pada perlakuan ini dapat memperbaiki sifat kimia tanah seperti $\mathrm{pH}$, C-organik, $\mathrm{P}_{2} \mathrm{O}_{5}$, K-dd terutama unsur hara Nitrogen $(\mathrm{N})$ yang sangat dibutuhkan oleh tanaman mengalami peningkatan sehingga akar tanaman dapat berkembang dengan baik dan dapat menyerap unsur hara lebih banyak. Unsur $\mathrm{N}$ yang diserap oleh akar digunakan untuk pertumbuhan secara keseluruhan, khususnya batang, cabang dan daun. Pemberian pupuk organik yang mengandung unsur $\mathrm{N}$ akan mendorong dan mempercepat pertumbuhan dan pertambahan tinggi tanaman.

Perkembangan dan pertumbuhan tanaman akan berlangsung pada fase pertumbuhan vegetatif. Fase pertumbuhan vegetatif pada tanaman berkaitan erat dengan tiga proses fifiologis yang penting yaitu pembelahan sel, pertambahan panjang sel, dan permulaan proses dari diferensiasi sel. Semua dari ketiga proses fisiologis tersebut membutuhkan kabohidrat, karena karbohidrat yang terjadi akan bergabung menjadi satu dengan persenyawaan-persenyawaan nitrogen untuk membentuk protoplasma pada tunas tanaman atau titik-titik tumbuh yang akan mempengaruhi pertambahan tinggi tanaman. Sementara ketersediaan karbohidrat yang dibentuk dalam tanaman dipengaruhi oleh ketersediaan unsur hara bagi tanaman tersebut (Mardianto, 2014).

Pada tabel 1, 2 dan 3 menunjukkan bahwa media tanam dengan komosisi 
pupuk guano belum mampu memberikan pengaruh terhadap pertumbuhan tanaman kentang hitam, hal ini diduga disebabkan oleh sifat pupuk guano yang relatif lambat proses dekomposisi nutrisi yang terkandung di dalamnya. Pupuk guano mengandung minimal nitrogen sebanyak 5\% kandungan ini lebih tinggi dari pupuk kandang yang hanya berkisar tidak lebih dari $1 \%$, bahkan pada guano segar kadar $\mathrm{N}$-nya sebesar 7\% ( Hasil uji PT. Petrokimia, 2015 dalam Taslim, 2018 ). Disamping itu pupuk guano juga mengandung unsur hara mikro seperti $\mathrm{Mg}$, $\mathrm{Mn}, \mathrm{Fe}, \mathrm{Zn}, \mathrm{Cl}$ dan $\mathrm{Cu}$. Namun demikian potensi tersebut belum dapat dimanfaatkan dengan baik atau belum dapat diserap oleh tanaman kentang hitam karena proses dekomposisi pupuk guano belum optimal.

\section{KESIMPULAN}

Media tanam perlakuan yang mengandung cocopeat dan pupuk kandang selain memperbaiki sifat fisik dan biologi tanah juga dapat meningkatkan unsur hara $\mathrm{N}, \mathrm{P}, \mathrm{K}$ pada media tanam, sehingga dapat dimanfaatkan tanaman kentang hitam untuk pertumbuhannya. Pada perlakuan media tanam yang mempunyai kandungan pupuk guano belum memberi pengaruh terhadap pertumbuhan tanaman kentang hitam diduga pupuk guano belum terdekompsisi dengan baik.

\section{UCAPAN TERIMA KASIH}

Penulis menyampaikan ucapan terima kasih kepada semua pihak yang telah membantu terlaksananya penelitian dan penulisan ini, terutama LPPM Universitas muhammadiyah Gresik sebagai penyandang dana

\section{DAFTAR PUSTAKA}

Anbuselvi, S. and M.H. Priya. 2013. Nutritional and anti nutritional constituent of Plectranthus rotundifolius. International Journal pharmaceutical Science review and research. 22(1): 213-215

Badan Pusat Statistik Kabupaten Gresik. 2016. Gresik Dalam Angka. Https://Gresikkab.Bps.Go.Id/Webs ite/Pdf Publikasi/KabupatenGresik-Dalam-Angka-2016.Pdf Diakses pada 10 November 2019

Duaja, Made Deviani. 2012.Analisis Tumbuh Umbi Kentang (SolanumTuberossum L.) di Dataran Rendah. Jurnal Agroteknologi, 1(2) : 88-97

Hidayat, I. M. (2016). Produksi Benih Sumber (G0) Beberapa Varietas Kentang dari Umbi Mikro. Jurnal Hortikultura, 21(3) : 197-205.

Human, Soeranto. 2015. Riset dan Pengembangan Sorgum dan Gandum untuk Ketahanan Pangan. Pusat Aplikasi Teknologi Isotop Dan Radiasi,Badan Tenaga Nuklir Nasional (Batan). 12 Hal

Kasutjianingati, Okta Sintya, Niniek Wihartiningseh, dan Prayitno. 2018. Produksi Benih Kentang Hasil Umbi Mikro dan Stek Mini pada Dataran Menengah di Jember.Journal of Applied Agricultural Sciences, 2(1) :10-19

Lestari, P., Ning Wikan Utami, Ninik Setyowati. 2015. Peningkatan Produksi dan Perbaikan Ukuran Umbi Kentang Hitam (Plectranthus Rotundifolius (Poir.) Spreng) Melalui Teknik Budidaya Sebagai Upaya Konservasi, Buletin Kebun Raya, 18 (2) : 59-69 
Jumadi dan Suhaili, Pertumbuhan Kentang Hitam ......

Mardianto, R. 2014. Pertumbuhan dan Hasil Cabai (capsicum annum 1.) dengan Pemberian Pupuk Organik Cair Daun Tithonia dan Gamal. Jurnal Gamma, Vol. 7 (1): 61 - 68.

Muzaiyanah, Siti dan Subandi. 2016. Peranan Bahan Organik dalam PeningkatanProduksi Kedelai dan Ubi Kayu pada Lahan Kering Masam. JurnalIptek Tanaman Pangan 11(2), 149-157

Prasetya, M. Hanafi Eka, Moch. Dawam Maghfoer dan Mudji Santoso. 2014. Pengaruh Macam Dan Kombinasi Bahan Organik Terhadap Pertumbuhan Dan Hasil Tanaman
Stevia (Stevia Rebaudiana B.)Jurnal Produksi Tanaman,2 (6) : 503-509

Rinanto, Yudi. 2014. Prospek Budidaya Kentang Hitam (Coleus tuberosus) di Lahan Kering. Proceding Seminar Nasional XI Pendidikan Biologi FKIP UNS. UNS Press.

Setiadi, 2009. Budidaya Kentang, Pilihan Berbagai Varietas dan Pengadaan Benih. Jakarta : Penebar Swadaya.

Suntoro. 2003. Peranan Bahan Organik Terhadap Kesuburan Tanah Dan Upaya Pengelolaannya. Surakarta : Sebelas Maret University Press 